aimed at deciding critical issues raised by the theory. An urgent need, as judged by the absence of mathematical papers in this symposium, is for the formulation of theories of nervous action based on relatively simple models which can be tested by experiment and by computer.

W. F. FLOYD

\section{MOISTURE MEASUREMENT}

\section{Humidity and Moisture}

Measurement and Control in Science and Industry. Editor-in-Chief: Arnold Wexler. Vol. 1 : Principles and Methods of Measuring Humidity in Gases. Edited by Robert E. Ruskin. Pp. xv +687. \$30. Vol. 2 : Measurement and Control in Science and Industry. Pp. $x v+634$. $\$ 27 \cdot 50$. (New York: Reinhold Publishing Corporation; London: Chapman and Hall, Ltd., 1965.)

EACH of these volumes is a collection of papers presented, under the sponsorship of the National Bureau of Standards and other United States interested organizations, in May 1963 at an International Symposium on Humidity and Moisture in Washington. Their appearance reflects the extraordinary change which has taken place in recent years in what had previously been one of the most neg. lected fields of physics. The subject of hygrometry rarely merits more than a paragraph or two in text-books of physics, and most science students meet it as a single unpleasant and unrewarding experiment in elementary physics. This stato of affairs is all the more inexplicable when the industrial importance of humidity and its control is borne in mind. The change has been brought about (and this is obvious from the subject matter of these volumes) principally by two factors.

The first is the increase in knowledge of the principles of automation, which has made it attractive to develop humidity sensors that can be suitably matched into servo-systems. The huge domestic market for air conditioning appliances in the U.S.A. promises adequate reward for successful solutions. The second is the need voiced by the armed services and by space agencios for successful methods of humidity measurement and control.

It is no surprise, therefore, that of the sixty-eight papers in Volume 1, no fewer than fifty-one originate in the United States or Canada; in Volume 2 the proportion is sixty-nine out of a total of seventy-four.

Volume 1 begins with an excollent review of the underlying theory, and the tables and charts and other computational aids used with that commonest of all hygrometers, the wet-and dry-bulb instrument. The remaining papers deal with various forms of this instrument, with dew-point, electric, spectroscopic and coulometric hygrometers, and finally with a number of miscollaneous methods which cannot be classified under the foregoing heads. The dew-point hygrometer has obviously become a much more attractive instrument following on the invention of Peltier electric cooling elements. It is interesting to find that the oldest and simplest hygrometer of all, the hair hygrometer, still has its uses.

The second volume is concerned with the applications of humidity measurement and control in various fields of interest. 'These covor biology and medicine, agriculture, controlled humidity chambers, air conditioning systems, process control, meteorology, radio propagation and atmospheric refraction. The range of the volume indicates the general importance of the subject.

In a publication of this type and especially in the second volume, involving so many separate contributions, it cannot be expected that all are of the same standard. The general level is high, however, and the quality of presentation is of an excellence one would expect of a publication sponsored by the National Bureau of Stand. ards. The index to Volume 1 is adequate, but that to Volume 2 is so terse as to be hardly of use. These two volumes, comprising a collection of papers representative of the present state of the art, can be recommended to all interested in hygrometry, with the usual regret that few individuals outside North America will be able to afford them.

W. H. J. CHILDS

\title{
COMMITTEE BOOK
}

\section{History of Mankind}

Cultural and Scientific Development. By Caroline F. Ware, K. M. Panikkar and J. M. Romein. Vol. 6: The Twentieth Century. Part 1: Introduction: The Development and Application of Scientific Knowledge. Pp. xlvi+ 1-646 + plates 1-20. Parts 2-4: The Transformations of Societies; The Self-Image and Aspirations of the Peoples of the World; Expression. Pp. xiii +647-1387+plates 21-64. (London: George Allen and Unwin, Ltd., 1966. Published for the International Commission for a History of the Scientific and Cultural Development of Mankind.) $168 s$. net.

'THIs instalment in Unesco's six volume History of Mankind is a vivid proof that committees cannot write books. The project is organized "under the mandate of the International Commission for a History of the Scientific and Cultural Development of Mankind", and the volume on the twentieth century (published in two volumes) has been written by a team of named authors working under the supervision of an author-editor and two co-authoreditors. A part of the exercise, which began in 1954, has required that authors should win the agreement or at least invite the dissent of a number of distinguished reviewers. The result, in many chapters, is that the footnotes which say who disagrees with whom are frequently more interesting than the necessarily pallid chapters which they accompany.

Dr. J. Bronowski, who contributed the chapter on "The New Scientific Thought", seems to have had a particularly rough ride. Dutifully, and with commendable brevity, he gives a straightforward Darwinian explanation of the principle of natural selection, only to earn for his pains the rebuke from Academician Ivan Malek that "the principle of natural selection is explained incorrectly, in a Malthusian fashion. . . Darwin was mistaken in making use of Malthusian ideas and referring to them, but this does not detract from the essential correctness of Darwin's teaching on natural selection". Academician Malek goes on to explain precisely what he means, and the authoreditors rally to the defence of their contributor by calling "attention to the fact that tho explanation presented in the text is that given by Darwin". But this is only a beginning. Poor Bronowski is taken to task for what he says about Marx and Engels, for allegedly failing to distinguish between "mechanistic determinism and doterminism as such", for his espousal of the positivist interpretation of quantum mechanics, and for many other misdemeanours as well. It is all good knockabout stuff, and no doubt faithfully representative of many Unesco meetings. But is it the history of mankind ?

JoHN MADDOX

\section{Catalogue of Meteorites}

With special reference to those represented in the collection of the British Museum (Natural History), By Max H. Hey. Third, revised and enlarged, edition. (Publication No. 464.) Pp. lxviii +637 . (London: British Museum (Natural History), 1966.) $120 s$.

STUDENTs of meteorites in Britain are exceptionally lucky to have the British Museum's large and comprehensive collection of meteorites at their disposal, and to have a tradition of meteorite study behind them which 